\title{
Latest Neoproterozoic to Mid-Cambrian age for the main deformation phases of the Transantarctic Mountains: new stratigraphic and isotopic constraints from the Pensacola Mountains, Antarctica
}

\author{
A. J. ROWELL ${ }^{1}$, W. R. VAN SCHMUS ${ }^{2}$, B. C. STOREY ${ }^{3}$, A. H. FETTER ${ }^{2}$ \& K. R. EVANS ${ }^{2}$ \\ ${ }^{1}$ Museum of Natural History, Division of Invertebrate Paleontology and Department of Geology, University of Kansas, \\ Lawrence, KS 66045, USA (e-mail: arowell@ukans.edu) \\ ${ }^{2}$ Department of Geology, University of Kansas, Lawrence, KS 66045, USA \\ ${ }^{3}$ British Antarctic Survey, High Cross, Madingley Road, Cambridge CB3 OET, UK
}

\begin{abstract}
New isotopic ages and a fresh understanding of stratigraphic relations among siliciclastic strata in the Pensacola Mountains along the northern margin of the East Antarctic craton result in removal of some constraints for the Proterozoic break-up of Rodinia and necessitate revision of the subsequent history of the East Antarctic margin. These rocks, formerly all included in the Patuxent Formation, were thought to be of mid-Neoproterozoic age, to have formed as a consequence of Rodinia rifting, and to have been deformed during a Neoproterozoic orogenic event. Our data show, in contrast, that these siliciclastic strata were deposited in two chronologically distinct basins. The older basin, in which the Hannah Ridge Formation (new name) accumulated, received sediment that contains detrital zircons of latest Neoproterozoic or Early Cambrian age. It was deformed and its contents uplifted and eroded prior to the late Mid-Cambrian in an orogenic event that we interpret as the early stage(s) of the Ross orogeny. The second basin formed later, accumulated turbidite-rich sediments of the redefined Patuxent Formation of Mid- and probably Late Cambrian age, and was subsequently deformed, possibly in Ordovician time. Review of both biostratigraphic and isotopic ages along the length of the Transantarctic Mountains indicates that almost everywhere the main episodes of deformation predate $500 \mathrm{Ma}$ and are thus older than latest Mid-Cambrian, rather than Ordovician, as they are commonly considered to be. Only in the accreted Bowers and Robertson Bay terranes of northern Victoria land, which reveal no clear record of pre-latest Mid-Cambrian or older folding, is the principal episode of Ross orogenic deformation demonstrably younger than Late Cambrian.
\end{abstract}

Keywords: Cambrian, Neoproterozoic, Antarctica, orogeny, absolute age.

The long Pacific-facing margin of the East Antarctic craton is a significant feature in global palaeogeographic models of Rodinia breakup in the Proterozoic and subsequent assembly of Gondwana (Moores 1991; Dalziel 1991; Hoffman 1991). The Antarctic geological record on which these models are based, however, is cryptic and the age of older sedimentary rocks, in particular, is commonly not well constrained. All rocks that yield this record are exposed in the Transantarctic Mountains, which border the East Antarctic craton and extend some $3500 \mathrm{~km}$ from northern Victoria Land to the Pensacola Mountains, adjacent to the Ronne Ice Shelf of the Weddell Sea (Fig. 1).

Supracrustal basement rocks of the Transantarctic Mountains have been the topic of numerous investigations during the past forty years, as summarized in extensive reviews by Laird (1991a) and Stump (1995). Cropping out beneath the Gondwanan overlap assemblage of Devonian through Jurassic age (Barrett 1991), they are commonly folded and variably metamorphosed. Collectively, they have been assigned to the Ross orogen (Stump 1995). Stratigraphic successions typically include interbedded sandstone and shale beds, widely interpreted as deep-water deposits, together with limestone units that retain clear evidence of shallow-water deposition. In some parts of the range, volcanic rocks are conspicuous components of the basement succession, including silicic ashfall deposits and ignimbrites. Elsewhere, pillow basalts are present. Details of the succession of supracrustal rocks vary markedly along the range between Victoria Land and the Pensacola Mountains, but broad patterns are evident for long distances parallel with the general strike of the Transantarctic Mountains. Nowhere is the base of the supracrustal succession known to be exposed, but for much of the distance between Byrd Glacier and the Pensacola Mountains (Fig. 1), the oldest rocks include thick interbedded sandstone and shale sequences either referred to the Beardmore Group or correlated with it (Grindley \& McDougall 1969). Although some recent investigations have questioned traditional interpretations of both the age and depositional setting of these rocks (Goodge 1997; Myrow \& Goodge 1999), many of the older supracrustal rocks are widely regarded as Neoproterozoic, of deep-water origin, and as providing evidence for deposition along a passive continental margin following rifting and drifting of the East Antarctic craton from Laurentia (e.g., Dalziel 1992; Storey et al. 1992).

In most interpretations, the subsequent rock record of the Ross orogen is considered to reflect transition to an active continental margin with early phases of deformation being referred to a Proterozoic Beardmore orogeny (Grindley \& McDougall 1969). Although the nature and timing of the Beardmore orogeny is disputed, the principal deformation of the orogen is widely interpreted to be an expression of the Ross orogeny, which most contributors regard as largely the product of a Late Cambrian to Early Ordovician episode of compression (Laird 1981, 1991a, b; Stump et al. 1986; Storey 


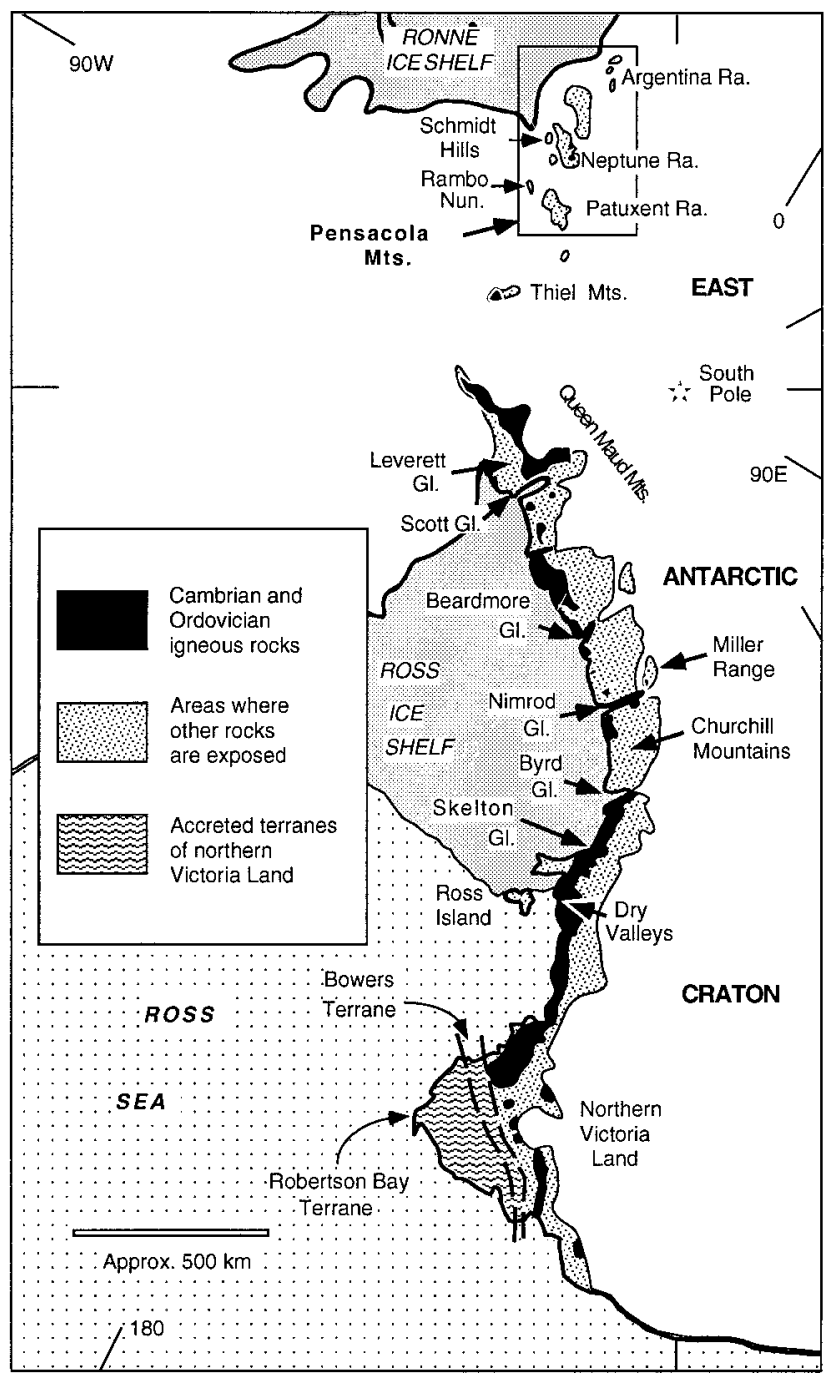

Fig. 1. The Transantarctic Mountains with location of major areas mentioned in the text and generalized rock outcrop areas. Principal outcrops of Cambrian and Ordovician igneous rocks of the Ross magmatic arc (including the Granite Harbour Intrusives and their correlates) differentiated in black. Mountain ranges enclosed in small rectangle form the Pensacola Mountains.

et al. 1996; Musumeci 1999). Basement reactivation, however, indicates that at least locally the Ross orogeny was transpressional and commenced in Early Cambrian time (Goodge et al. 1993a,b). Although the geological record of the Ross orogen varies along the Transantarctic Mountains, a geographically persistent feature was the development of a magmatic arc. This arc is most typically expressed by the Granite Harbor Intrusives and their correlates that crop out along the entire length of the range (Grindley \& Warren 1964; Borg \& DePaolo 1991; Fig. 1).

In this paper, we present new stratigraphic and geochronological data from the Pensacola Mountains and reexamine the history of the Ross orogen at this, its northern termination. We conclude that the oldest exposed strata are not of midNeoproterozoic age and both deposition and deformation occurred in a compressed timeframe relative to traditional views. Indeed, taking the remainder of the Transantarctic Mountains into account, we recognize that along most of its

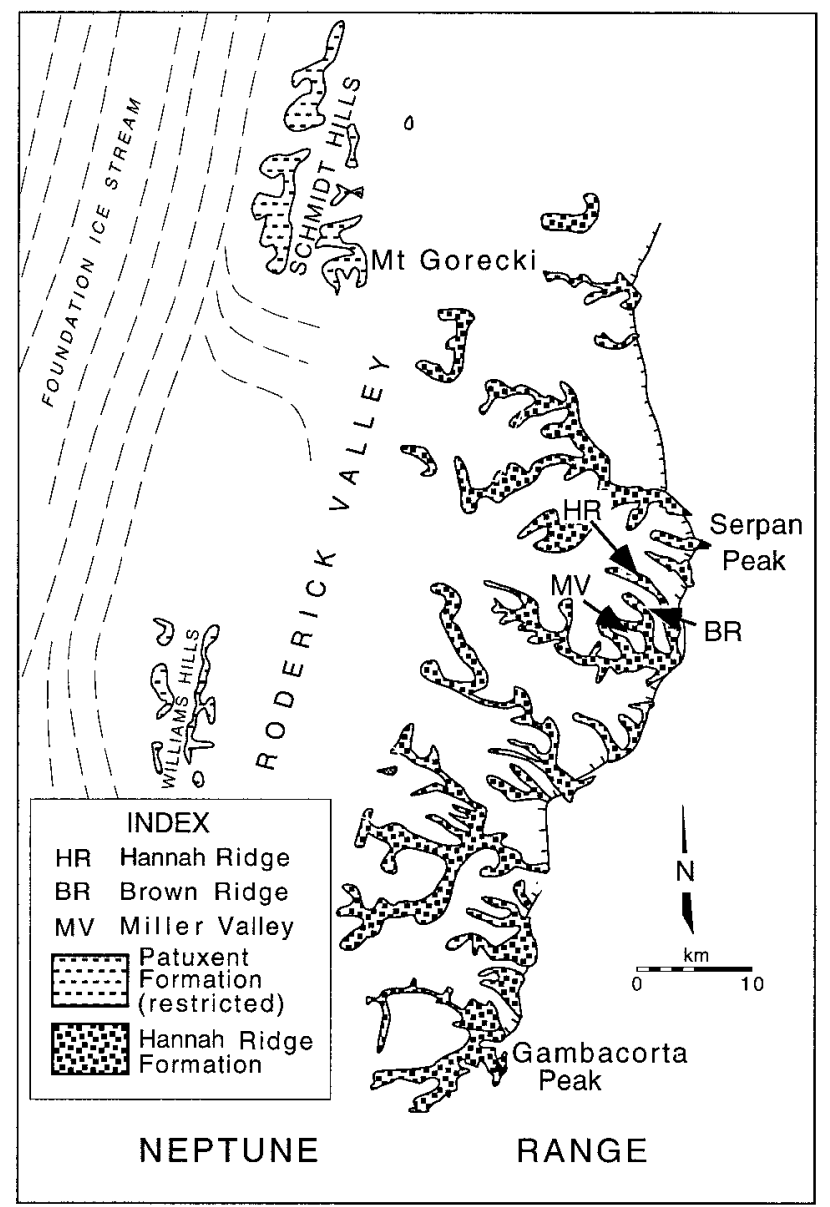

Fig. 2. Localities in the eastern and western Neptune Range mentioned in the text. Map also shows areas in which metagreywacke and slate of the restricted Patuxent and Hannah Ridge formations are distinguished.

length, peak deformation of the Ross orogen occurred much earlier in Cambrian time than was formerly appreciated.

\section{Regional geology in the Pensacola Mountains}

Outcrops of supracrustal rocks are widespread in the Pensacola Mountains. We studied them in the Patuxent Range, Neptune Range, the northern end of Rambo Nunataks, and the Argentina Range (Fig. 1).

A thick succession of shales and turbidite-rich sandstones occurs over much of the western part of the area. They are widely considered to be the oldest strata in the region and were mapped collectively as the Patuxent Formation (Schmidt et al. 1964, 1965; Schmidt \& Ford 1969). These strata are the major focus of the present study and are discussed in more detail below. Younger beds are seen in stratigraphic contact with the Patuxent Formation only in the eastern Neptune Range (Schmidt \& Ford 1969; Figs 2 and 3). Here, beds mapped as the Patuxent Formation are overlain with marked angular unconformity by the Nelson Limestone.

Fossil collections made during the early mapping of the region established that the Nelson Limestone was probably upper Middle Cambrian (Palmer \& Gatehouse 1972; Tröger \& Weber 1985). We collected Amphoton oatesi Palmer \& Gatehouse 1972 from several horizons in the Nelson 


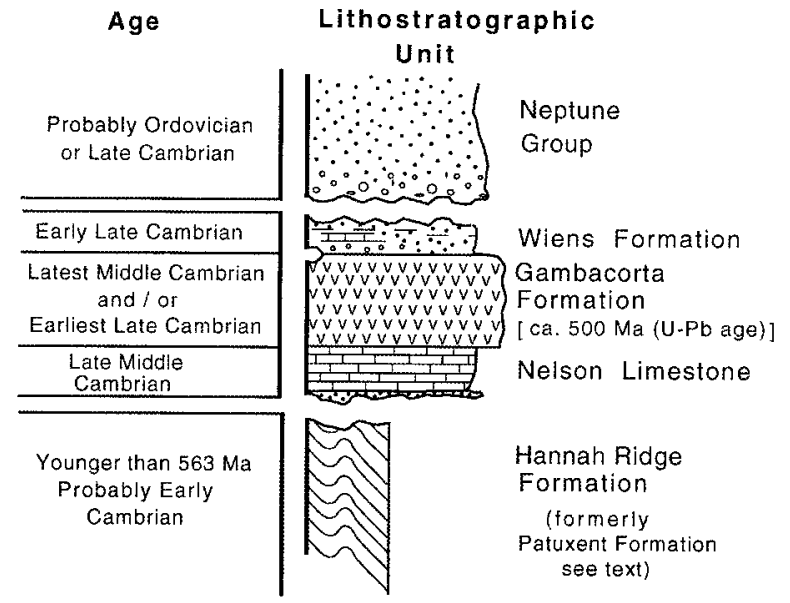

Fig. 3. Generalized stratigraphic succession of the older basement rocks in the eastern Neptune Range.

Limestone. Our highest collection, some $400 \mathrm{~m}$ above the base of the Nelson Limestone near what we infer to be the top of the unit, includes Kootenia styrax Palmer and Gatehouse, an element of the Amphoton oatesi fauna (Palmer \& Gatehouse 1972). The genus Amphoton itself is now known to be confined to the upper Middle Cambrian but does not range to the very top of the upper Middle Cambrian (Encarnación et al. 1999). The basal siliciclastic beds of the Nelson Limestone have not yielded a fauna, but there is no indication of any significant stratigraphic hiatus within them. A small collection from the southern Neptune Range has been identified as Upper Cambrian (Solov'ev et al. 1984), but we are unable to confirm this conclusion. It is based largely on acrotretid brachiopod valves referred to the genus Dactylotreta Rowell \& Henderson 1978. This genus is also now known from upper Middle Cambrian rocks (Zell \& Rowell 1988). The palaeontological data thus suggest that the entire Nelson Limestone is upper Middle Cambrian as Palmer \& Gatehouse (1972) tentatively concluded.

Carbonate deposition was terminated by volcanism (Schmidt et al. 1965, 1978; Storey et al. 1996). Felsic volcanic rocks of the Gambacorta Formation (Fig. 3) conformably overlie the Nelson Limestone; locally, the top $10 \mathrm{~m}$ of the limestone are interbedded with lapilli tuff and the boundary is gradational (Storey et al. 1996). Volcanic activity was seemingly associated with a caldera located near Gambacorta Peak, where the formation is probably over $1500 \mathrm{~m}$ thick and consists of a variety of interbedded ash flows, pyroclastic flows, lava flows, and agglomerates (Schmidt et al. 1978). Millar \& Storey (1995) reported a U-Pb zircon age of $501 \pm 3 \mathrm{Ma}$ from the Gambacorta Formation, dating its age of eruption. Additional analyses of the formation by Van Schmus et al. (1997) suggest that both a volcanic tuff from outside the vent and a felsite porphyry from the caldera fill were formed $500 \pm 5 \mathrm{Ma}$ ago and are probably coeval.

The overlying Wiens Formation (Fig. 3) is mostly locally derived and the product of erosion and breakdown of the Gambacorta Formation (Storey et al. 1996). The only fossils recovered in this study and in prior fieldwork (Storey et al. 1996) consist of poorly preserved lingulides referred to Notiobolus sp. As with most lingulides, the taxon is not very diagnostic of age and merely confirms that the strata are lower Palaeozoic. Over most of its outcrop area, the Wiens Formation is conformable upon the underlying volcanic strata.
Locally, in the southern part of the Neptune Range, however, syndepositional uplift was inferred (Storey et al. 1996) to explain thickness variations and onlap relations of the Wiens Formation upon the underlying volcanics of the Gambacorta Formation.

An episode of deformation, uplift, and erosion preceded deposition of the overlying Neptune Group (Fig. 3). The base of the Neptune Group is an unconformity (Schmidt et al. 1965) and, although the angular discordance between the basal beds of the group and the underlying strata is typically small, considerable overstep is recognizable along the length of the eastern Neptune Range. The basal beds of the group variously rest on the Wiens, Gambacorta, Nelson Limestone, and Patuxent formations. The group as a whole is regarded as the depositional product of a major alluvial fan complex (Storey et al. 1996), but its age is not well constrained. Some authors have considered the Neptune Group to be Devonian (Barrett 1991); others have placed it within the interval Ordovician through Devonian (Schmidt et al. 1978; Laird 1981; Frischbutter 1981; Storey et al. 1996). Storey et al. (1996), considered it was probably Ordovician because what they regarded as growth folds in the underlying Wiens Formation appear locally to have influenced sedimentary patterns in the lower beds of the Neptune Group.

\section{The Hannah Ridge and Patuxent formations}

All deformed thick successions of sandstones and shales in the Pensacola Mountains were mapped initially as the Patuxent Formation (Schmidt et al. 1964, 1965; Schmidt \& Ford 1969). On the basis of $\mathrm{Rb}-\mathrm{Sr}$ isotopic data from a felsite of the Gorecki Felsite Member, one of the members of the formation in the Schmidt Hills of the western Neptune Range, the Patuxent Formation was considered to be mid-Proterozoic in age (Eastin 1970; Faure et al. 1979). Subsequent U-Pb zircon analysis of samples from the same member (Millar \& Storey 1995; Van Schmus et al. 1997) showed the interpretation of the $\mathrm{Rb}-\mathrm{Sr}$ data was in error and that the beds were about $500 \mathrm{Ma}$ old. With this new information, the relationship of the Gorecki Felsite Member to the beds mapped as Patuxent Formation beneath the Nelson Limestone on the east side of the Neptune Range was not clear (Millar \& Storey 1995). Our new interpretation of regional relationships among the various outcrop areas of beds initially referred to the Patuxent Formation reveals a relatively simple pattern. Although superficially similar, these strata were deposited in two distinct basins of different age. Furthermore, the basins have had different tectonic histories.

Rocks initially referred to the Patuxent Formation in the western part of the Pensacola Mountains, (outcrops in the Patuxent Range, Rambo Nunataks, and Schmidt and Williams hills of the western Neptune Range, Fig. 2), consist of thick sucessions of turbidite-rich sandstones and shales deformed into simple folds. In the Patuxent Range, for example, the beds occupy broad, open, subhorizontal folds with near-vertical axial surfaces and a single well-developed axial-planar slaty cleavage (Schmidt et al. 1964). Folds trend approximately north-south in the southern part of the range and are NE-SW in the northern part of the area. Fold axes plunge gently north or south throughout the mountain range (Schmidt et al. 1964). The thickness of beds in this area is unknown, but has been estimated to be 'several tens of thousands of feet' (Schmidt et al. 1965). Schmidt et al. (1964) reported numerous sections 
600-900 m thick but, because of the monotonous lithology of alternating shale and greywacke sandstone beds, these sections could not be correlated. The Patuxent Range has received little study since its first reconnaissance investigation. This early work revealed that many of the sandstones were graded and their basal surfaces bore flute casts. The rocks were therefore interpreted as having been deposited by turbidite currents in a moderately deep marine basin (Schmidt et al. 1964). A similar sequence of rocks with a comparable level of deformation crops out at the northern end of Rambo Nunataks (Schmidt \& Ford 1969; Fig. 1), where Storey et al. (1996) measured some $800 \mathrm{~m}$ of beds on one limb of a major fold. As in the Patuxent Range, a single cleavage is present. In the Schmidt and Williams hills of the western Neptune Range, turbidite-rich sandstones and shales resemble those of the Patuxent Range and Rambo Nunataks in their degree of deformation. They differ from outcrops in these latter two areas, however, in that the sedimentary rocks are interbedded with and intruded by large volumes of both mafic and felsic igneous rocks (Schmidt et al. 1965, 1978; Schmidt \& Ford 1969; Frischbutter \& Vogler 1985; Storey et al. 1992). Because these similar western turbidite-rich siliciclastic rocks include outcrops in the Patuxent Range, we propose that they continue to be called the Patuxent Formation, but we use the term in a new restricted sense because, as discussed below, it does not include any strata in the eastern Neptune Range.

Strata originally referred to the Patuxent Formation in the eastern Neptune Range (Schmidt et al. 1965), east of the glacier that occupies Roderick Valley (Figs 2 \& 3), are much more deformed. We place them in a new stratigraphic unit, the Hannah Ridge Formation. Rocks of this formation commonly form talus-covered slopes, and no long continuous stratal exposures are known. Hannah Ridge (Fig. 2) is taken as the type locality, although many other ridges in the eastern Neptune Range would be equally informative. Unlike outcrops of the now restricted Patuxent Formation to the west, multiple phases of folding have been documented in these strata and typically two cleavages are developed (Frischbutter 1982; Storey et al. 1992). At least locally, in the southeastern part of the Neptune Range, folding is tightly isoclinal and a pervasive axial-plane cleavage is present, and is developed even in coarse-grained sandstone beds. The cleavage obliterates most sedimentary stuctures and, in contrast with the Patuxent Formation, we have not seen examples of turbidity current deposition.

The difference between the beds of the restricted Patuxent Formation and the Hannah Ridge Formation is not merely a difference in deformation history; the beds are of markedly different ages and formed in different basins. The Gorecki Felsite Member, which overlays and is overlain by thick turbidite-rich successions of the restricted Patuxent Formation in the Schmidt Hills, documents their relative ages because it affords correlation from the west across Roderick Valley and into the stratigraphic succession of the eastern Neptune Range.

Initial reconnaissance mapping of the area (Schmidt et al. 1978) recognized that the Gorecki Felsite Member at its type locality, Mt Gorecki in the Schmidt Hills, included porphyritic tuffs and flow breccias varying in thickness from 2 to $100 \mathrm{~m}$. Some of the tuffs appeared to be ash flows. The member crops out in both the Schmidt and Williams hills (Fig. 2) where it is associated with turbidite-rich sandstones and argillites. Our reexamination of the member at its type locality reveals that although laminated tuffaceous beds occur, particularly in its upper part, much of it consists of an oligomictic, felsic tuff

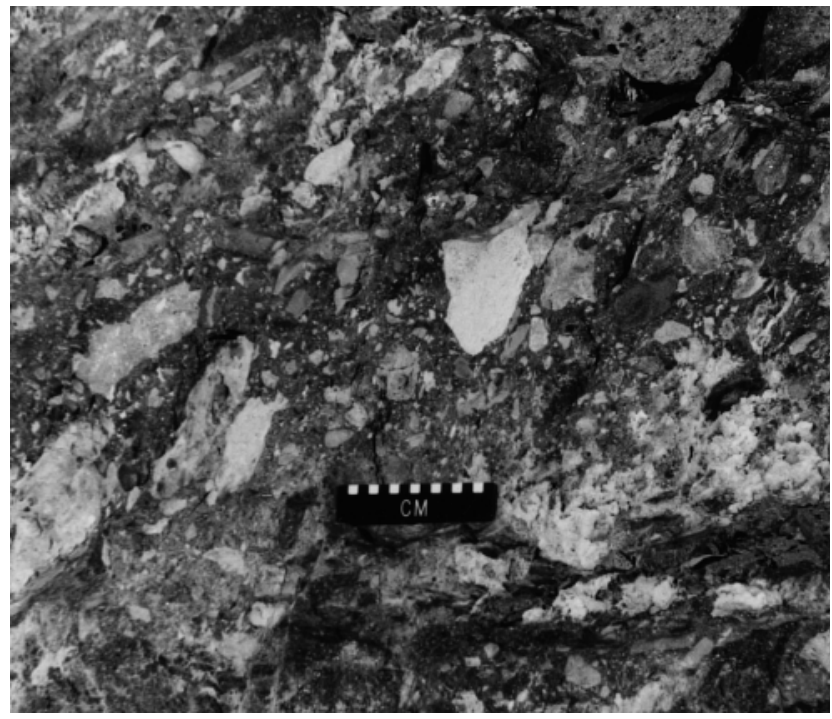

Fig. 4. Matrix-supported limestone-rich breccia of the Gorecki Member of the Patuxent Formation, southern point of eastern ridge of Mt Gorecki, Schmidt Hills.

megabreccia unit more than $100 \mathrm{~m}$ thick. Most of the blocks are very large, some more than $10 \mathrm{~m}$ across; blocks are distributed throughout the megabreccia, and are not concentrated at any one level. Many of the larger tuff blocks are themselves agglomerates and contain clasts of limestone. At the southern end of Mt Gorecki, limestone clasts are dominant (some $50-60 \%$ of the clasts), vary in size from about $0.01 \mathrm{~m}$ to nearly $1 \mathrm{~m}$, and are typically angular. The breccia here, like the megabreccia as a whole, is very poorly sorted and blocks are matrix supported (Fig. 4). The limestone clasts are lithologically variable and include oolitic grainstone, burrowed packstone, and laminated carbonate mudstone. Their lithology suggests the provenance area included rocks deposited on a carbonate shelf with depositional settings varying from peritidal to subtidal and below wave-base. The Gorecki Felsite Member at this locality appears to be a submarine gravitydriven mass movement deposit that may have been associated with collapse of a carbonate shelf margin caused by sudden loading of volcanic material.

Fossiliferous limestone clasts in the Gorecki Felsite Member show that this unit is Phanerozoic, not Proterozoic; the modest fauna includes sponge spicules and a hyolith (Evans et al. 1994; Rowell et al. 1995). Although not diagnostic, the fauna and carbonate lithologies could all have been derived from the Nelson Limestone to the east. Subsequent U-Pb zircon ages from Mt Gorecki and the Williams Hills constrain the age of the felsite member. Millar \& Storey (1995), who dated a felsite from Mt Gorecki, suggested $500 \pm 8 \mathrm{Ma}$ as the emplacement age. Van Schmus et al. $(1995,1997)$ found that zircons from a quartz-porphryry tuff from the megabreccia at Mt Gorecki clustered near discordia at c. $500 \mathrm{Ma}$ and a felsite porphyry, regarded as part of the Gorecki Felsite Member and intruded into turbidite deposits in the northwest Williams Hills, produced zircons with an age of $502 \pm 3 \mathrm{Ma}$. They concluded that the Patuxent Formation exposed in the western Neptune Range was deposited about 500-505 Ma ago. The isotopic age of the Gorecki Felsite Member in the west is thus the same as that of Gambacorta Formation to the east, within experimental error. Given the setting, we interpret the shelf succession of the eastern Neptune Range as source for material in the 
Gorecki Felsite Member. We postulate that the caldera event, documented by thick pyroclastic flows and agglomerates of the Gambacorta Formation near Gambacorta Peak (Schmidt et al. 1978), was the triggering mechanism for the mass movement that produced the Gorecki Member. If this interpretation is correct, the restricted Patuxent Formation is broadly the same age as the Gambacorta Formation, and part of the siliciclastic section may be younger. In contrast, the Hannah Ridge Formation is older than the Gambacorta Formation; indeed, it is in fact older than the Nelson Limestone (Fig. 3).

\section{New detrital zircon ages}

Isotopic analyses of detrital zircons from the two formations afford a means of testing the correlation and further constraining the age of the older Hannah Ridge Formation. We determined U-Pb detrital zircon ages for three samples of the Patuxent Formation, one from the type locality in the Patuxent Range, the other two from Rambo Nunataks. We also obtained U-Pb detrital zircon ages from one sample of the Hannah Ridge Formation to provide a maximum depositional age for the unit.

Isotope dilution $\mathrm{U}-\mathrm{Pb}$ analyses of zircons were determined at the Isotope Geochemistry Laboratory (IGL), University of Kansas. The data reported here (Table 1) were obtained using standard isotope dilution techniques (Van Schmus et al. 1997), except that sample sizes were much smaller $\left(<10^{-5} \mathrm{~g}\right)$, blanks are lower $\left(<4 \times 10^{-12} \mathrm{~g}\right)$, and a new ion-counting system on our VG Sector mass spectrometer was used to measure isotopic ratios. Hand-picked zircon grains were air-abraded (Krogh 1982) prior to dissolution. They were dissolved and $\mathrm{Pb}$ and $\mathrm{U}$ extracted using procedures modified after Krogh (1973) and Parrish (1987). Samples were total-spiked with a mixed ${ }^{205} \mathrm{~Pb}-{ }^{235} \mathrm{U}$ tracer solution and a miniaturized version of the $\mathrm{HCl}$ column chemistry of Krogh (1973) was used. Pb isotopic compositions were analysed on single Re filaments using silica gel and phosphoric acid. $\mathrm{Pb}$ data were corrected for mass discrimination as determined by analysis of NBS SRM-982 equal-atom $\mathrm{Pb}$ and monitored by analysis of NBS SRM-983 radiogenic $\mathrm{Pb}$. Uranium was loaded on the same filament with the $\mathrm{Pb}$ and analysed as $\mathrm{UO}_{2}^{+}$; uranium fractionation was monitored using NBS SRM U-500. Uncertainties in U/Pb ratios due to uncertainties in fractionation and mass spectrometry for typical analyses are normally $\pm 0.5 \%$; in some instances weak signals from the single-crystal samples caused uncertainties to range up to $\pm 2 \%$ or more. Radiogenic ${ }^{208} \mathrm{~Pb},{ }^{207} \mathrm{~Pb}$, and ${ }^{206} \mathrm{~Pb}$ were calculated following the PBDAT program of Ludwig (1993a), which corrects for common $\mathrm{Pb}$ using a weighted average of measured laboratory blank $\mathrm{Pb}$ and nonradiogenic original $\mathrm{Pb}$ based on Stacey \& Kramers (1975) model $\mathrm{Pb}$ for the age of the sample. Uncertainties in radiogenic $\mathrm{Pb}$ ratios are represented in Table 1 as corresponding uncertainties in the respective ages. Decay constants used were $0.155125 \times 10^{-9} \mathrm{a}^{-1}$ for ${ }^{238} \mathrm{U}$ and $0.98485 \times 10^{-9} \mathrm{a}^{-1}$ for ${ }^{235} \mathrm{U}$. Blanks ranged from $c$. 2 to 5 pg total $\mathrm{Pb}$. Data were plotted and regressed using the ISOPLOT program of Ludwig (1993b).

\section{Patuxent Formation}

Table 1 includes U-Pb isotopic data for Patuxent Formation detrital zircons from sample R.2356.5 (Patuxent Range) and samples V93-12 and V93-14 (Rambo Nunataks). For V93-12 and V93-14 the analyses are for multi-grain fractions, but for R.2356.5 the data include results from 11 single-zircon analyses as noted. Because of similarities among these three samples, all 33 analyses are presented together (Fig. 5). Two groups of zircon can be recognized. (1) Most zircons fall along a broad array between $500 \mathrm{Ma}$ and $1000 \mathrm{Ma}$. This population may represent c. $500 \mathrm{Ma}$ plutonic zircons having a large $c .1000 \mathrm{Ma}$ inherited component, as found for granitoid rocks in the region (Van Schmus et al. 1997), or detrital zircons from sources of various ages, or both. (2) Zircons from a smaller population representing a young source have a small to negligible inherited component (inset, Fig. 5). This population suggests a provenance with crystallization ages of about $500 \mathrm{Ma}$. Four single-grain analyses from R.2356.5 (A, B, C, D) yield an average ${ }^{207} \mathrm{~Pb} /{ }^{206} \mathrm{~Pb}$ age of $496 \pm 12 \mathrm{Ma}$ (Fig. 5), which is currently our best estimate for the maximum depositional age of the Patuxent Formation as restricted in this paper. Multi-grain analyses C, D, and E from V93-12 are consistent with this age; single-grain analysis $\mathrm{T}$ from R.2356.5 may have a small amount of inheritance or be slightly older.

\section{Hannah Ridge Formation-Miller Valley, eastern Neptune Range}

Table 1 includes $\mathrm{U}-\mathrm{Pb}$ isotopic data for Hannah Ridge Formation detrital zircons from sample R.4707.1, which was collected from rocks of the Hannah Ridge Formation on Brown Ridge, Miller Valley, where it underlies the Nelson Limestone. Figure 6 shows eight analyses in a broad array from c. $550 \mathrm{Ma}$ to $c .1050 \mathrm{Ma}$. Contrary to the case for the preceding samples, no zircons plot close to or below $500 \mathrm{Ma}$. Because most analyses were multigrain, we cannot be sure if the array is due only to c. $550 \mathrm{Ma}$ zircons with inheritance (cores) or to mixtures of c. $550 \mathrm{Ma}$ and c. $1050 \mathrm{Ma}$ single grains. However, based on the prevalence of inheritance in zircons from igneous rocks in this region (Van Schmus et al. 1995, 1997), we suspect that most of the array is due to inheritance (cryptic cores). The presence of one single-grain fraction close to $550 \mathrm{Ma}$ (analysis A, sample R.4707.1) places tighter limits on the depositional age of this sandstone. If we assume this fraction has no inheritance, the ${ }^{207} \mathrm{~Pb} /{ }^{206} \mathrm{~Pb}$ age of $561 \pm 2$ Ma establishes the older limit for the depositional age. The younger limit for the depositional age is unconstrained by zircon data, but it must predate deposition of the Nelson Limestone, which unconformably overlies it.

These new $\mathrm{U}-\mathrm{Pb}$ detrital zircon ages from the Patuxent Formation together with previously published information (Millar \& Storey 1995; Van Schmus et al. 1997) confirm that each of its major outcrop areas includes strata that are $500 \mathrm{Ma}$ or younger; this is consistent with the correlation deduced from regional geology. The age of the detrital zircons in the Hannah Ridge Formation has important consequences for the earlier geological history of the region. The strata are not Mesoproterozoic or even middle Neoproterozoic as formerly thought. They are latest Neoproterozoic $(<561 \pm 2 \mathrm{Ma})$ to early Middle Cambrian (pre-Nelson Limestone).

\section{Tectonic history of the Pensacola Mountains}

We undertook no detailed structural or kinematic studies in the Pensacola Mountains. Our contribution is based on regional geological relationships keyed to new age constraints, both $\mathrm{U}-\mathrm{Pb}$ zircon isotopic dates and some faunal data. Recent revision of the Cambrian time scale is important in correlating these two sources of information about time. New studies (Shergold 1995; Landing et al. 1997, 1998; Landing \& Westrop 1998; Davidek et al. 1998; Bowring \& Erwin 1998) show that Cambrian series boundaries are significantly younger than they were thought to be at the beginning of the decade. The base of the Middle Cambrian appears to be at $510 \mathrm{Ma}$, the base of the Upper Cambrian is regarded as being at $500 \mathrm{Ma}$, and the base of the Ordovician at $490 \mathrm{Ma}$. The age of the base of both the Middle Cambrian (Landing et al. 1998) and the Ordovician (Davidek et al. 1998) are moderately well constrained by 


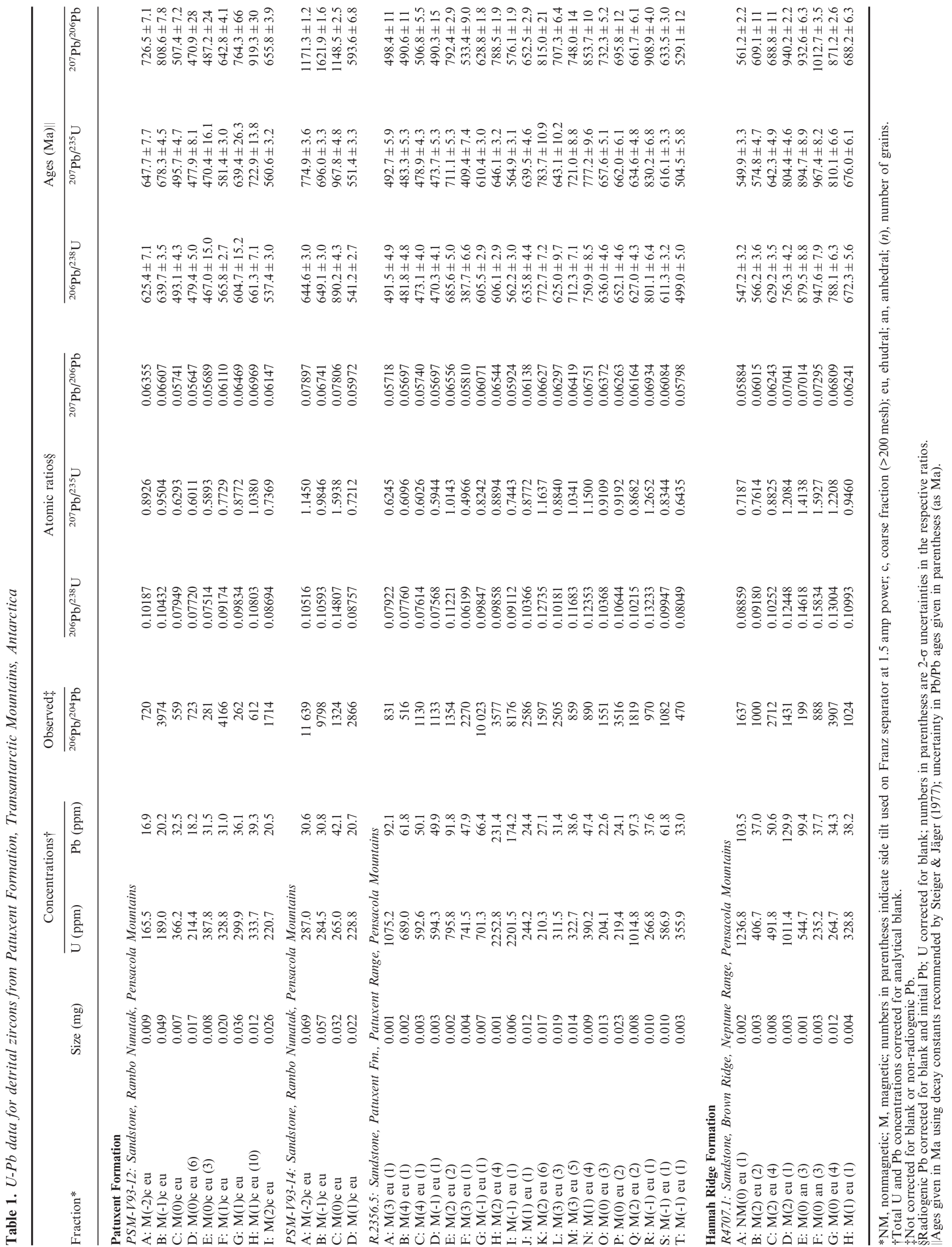




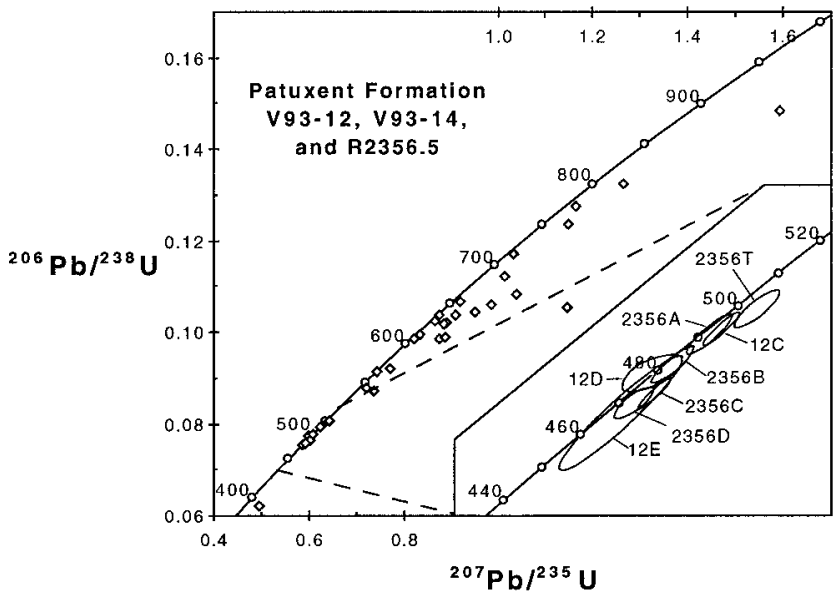

Fig. 5. Detrital zircon results (Table 1) for Patuxent Formation samples from the Patuxent Range (R2356.5) and Rambo Nunataks (V93-12, -14). Diamonds show all data and reveal that they spread generally from $c .500$ Ma towards Mesoproterozoic upper intercepts. The spread probably includes many zircons that crystallized c. $500 \mathrm{Ma}$ with significant inherited components, although the array could also include some individual grains from late Neoptroterozoic sources. The inset shows results from several analyses that apparently have very little, if any, inherited component. Single-grain analyses A, B, C, and D from sample R2356.5 (Table 1) set a maximum depositional age of $496 \pm 12 \mathrm{Ma}$ (mean of ${ }^{207} \mathrm{~Pb} /{ }^{206} \mathrm{~Pb}$ ages).

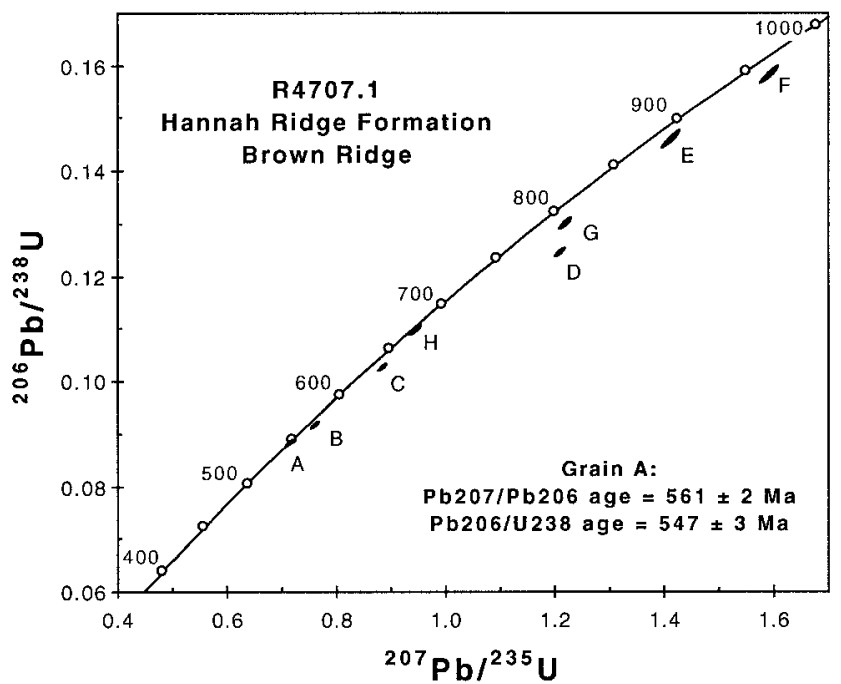

Fig. 6. Results for detrital zircons from the Hannah Ridge Formation sample collected on Brown Ridge (R4707.1). The ${ }^{207} \mathrm{~Pb} /{ }^{206} \mathrm{~Pb}$ age from single-grain analysis $\mathrm{A}$ (Table 1 ) sets a maximum depositional age of $561 \pm 2 \mathrm{Ma}$.

faunally controlled high-precision zircon ages. The age of the base of the Upper Cambrian, at $500 \mathrm{Ma}$, however, has considerable biostratigraphic uncertainty and associated isotopic ages have wide 95\% confidence limits (Jago \& McNeil 1997; Jago \& Haines 1998; Davidek et al. 1998). Bowring \& Erwin (1998), in a recent review, however, accepted Shergold's (1995) $500 \mathrm{Ma}$ estimate for this boundary, which was itself founded on the work of Perkins \& Walshe (1993) in Tasmania. Nevertheless, although the age of this boundary lacks precision, it is apparent that an age of $500 \mathrm{Ma}$ is close to the Middle Cambrian-Upper Cambrian boundary (Encarnación et al.
1999) and provisionally we are adopting this value for subsequent discussion. $500 \mathrm{Ma}$ is clearly not Early Ordovician, nor is it adjacent to the Cambro-Ordovician boundary, as was thought only a few years ago.

\section{The origin of the Ross orogen and early Ross movements}

The Hannah Ridge Formation provides the oldest record of the geological history of the region, but the age of the formation can be fixed only to within some $60 \mathrm{Ma}$. The strata are younger than $561 \pm 2 \mathrm{Ma}$ and older than the Nelson Limestone, which is late but not latest Mid-Cambrian and thus slightly older than $500 \mathrm{Ma}$. Purely from a stochastic point of view, an Early Cambrian age is probable, although not certain. However, we do not know precisely when its depositional basin was initiated. Indeed, the tectonic setting of the basin has few limiting constraints. Previously, it was considered to have formed with the mid-Neoproterozic break-up of Rodinia (Storey et al. 1992) as an intracratonic basin. Although this may have been the case, we have no evidence to support such an early history. We can demonstrate, however, that strata within it are not the counterpart of the Windermere Group of western Laurentia (e.g., Dalziel 1992), because they are too young. More probably the basin was initiated or perhaps reactivated in latest Neoproterozoic or Early Cambrian time. It was suggested previously (Rowell et al. 1992) that the thick Lower Cambrian (Botomian) reefal limestones of the Schneider Hills in the Argentina Range to the east (Fig. 1) could be the shallow-water equivalent of at least part of what we are now calling the Hannah Ridge Formation. Our new data make this suggestion more probable (Fig. 7). The Botomian reefs could have marked the seaward limit of a carbonate platform developed upon the East Antarctic craton, while Hannah Ridge siliciclastics accumulated in an offshore basin towards the paleo-Pacific Ocean.

At an unknown time prior to the late Mid-Cambrian, strata of the Hannah Ridge Formation were deformed, uplifted and eroded. This deformation is the most intense known in the area and previously has been regarded as an expression of the Beardmore orogeny (Grindley \& McDougall 1969). The terminology for episodes of deformation in the Transantarctic Mountains is in a state of flux and in danger of obscuring what we know of deformational history. Initially, all folding of basement rocks beneath the Gondwana overstep assemblage was referred to the Ross orogeny (Gunn in Gunn \& Warren 1962). With the recognition of unconformities beneath fossiliferous Cambrian within the basement successions, Grindley \& McDougall (1969) differentiated a Beardmore orogeny, which was thought to be a late Precambrian event associated with widespread magmatic activity. In this context, the Ross orogeny was restricted to later events considered to have occurred between $520 \mathrm{Ma}$ and $450 \mathrm{Ma}$. The overlying unconformity and folding of the Hannah Ridge Formation was one of two cited examples of Beardmore folding. The status of this orogeny as a distinct event has been questioned repeatedly (Stump et al. 1986; Pankhurst et al. 1988; Encarnación \& Grunow 1996; Goodge 1997). Presently, the only documented Neoproterozoic folding is confined to southern Victoria Land where, in the Skelton Glacier area (Skinner 1982; Rees et al. 1990), two generations of folds predate intrusion of small granitic and quartz dioritic stocks of latest Neoproterozoic age, 551 \pm 4 Ma (Rowell et al. 1993; Encarnación \& Grunow 1996). Elsewhere, isotopic dates of 
WEST

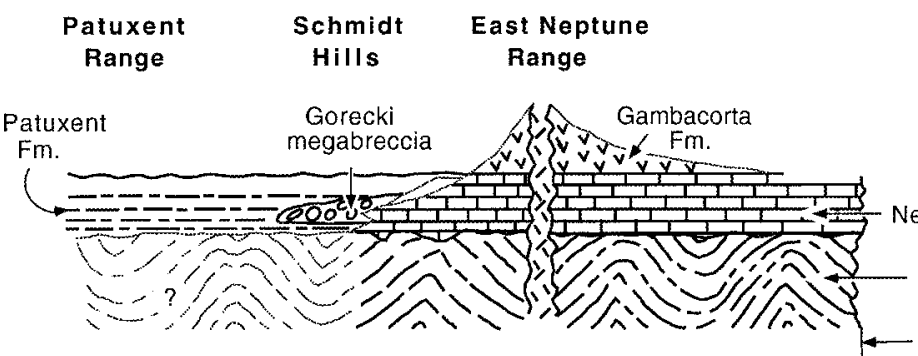

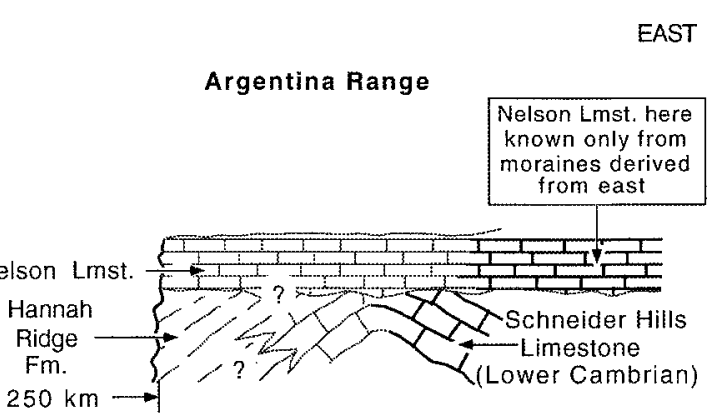

EAST

Fig. 7. Diagrammatic cross section from the Argentina Range to the Schmidt Hills and Patuxent Range at $c$. 500 Ma showing inferred facies relationships between shallow and deep-water rocks above and below the sub-Nelson Limestone unconformity, see text for details. Parts of diagram in finer line are not controlled by outcrop data.

zircon and titanite from igneous bodies previously considered to be Proterozoic and associated with the Beardmore orogeny are Early Cambrian or younger (Pankhurst et al. 1988; Encarnación \& Grunow 1996). Rather than refer to a Beardmore orogeny, as such, Encarnación \& Grunow (1996) chose to speak of a 'pre-530 Ma deformation' in the Scott Glacier and southern Victoria Land areas. Goodge (1997) also questioned the Beardmore orogeny as a unique event and suggested that early folding be regarded as an initial expression of a diachronous 'Ross orogenic cycle'. In contrast, Stump et al. (1999), have recently advocated using the term Beardmore orogeny to cover pre-530 Ma deformation in the Transantarctic Mountains. The problem is to some extent a semantic one, but we too prefer a closer adoption of the original meaning for the term Ross orogeny because it is not always possible to determine whether deformation age is pre or post-530 Ma. We use the phrase here, as it was initially used for all pre-Devonian deformation of the 'Ross System' (Gunn in Gunn \& Warren 1962; Laird 1963). In present-day terminology, the 'Ross system' would include all pre-Devonian supracrustal rocks of the region. With this approach, folding of the Hannah Ridge Formation is an early expression of the Ross orogeny.

In the Pensacola Mountains, the earliest episode of deformation was completely amagmatic. Minimally one phase of folding occurred that produced the tight isoclines now bevelled by the sub-Nelson Limestone unconformity. Given that two cleavages have been recorded (Frischbutter 1982; Storey et al. 1992), these beds were potentially deformed twice prior to the late Middle Cambrian (Fig. 8), but detailed structural studies are needed to confirm the possibility. The folding can be constrained only as having occurred between $561 \pm 2 \mathrm{Ma}$ and c. $500 \mathrm{Ma}$, but if we are correct in our inference that some part of the Hannah Ridge Formation is Botomian, then timing of at least the latest episode of this pre-500 Ma deformation can be further limited as being post $520 \mathrm{Ma}$ (Bowring \& Erwin 1998) and pre-500 Ma. Overall, this deformation probably occurred during the Early Cambrian, but a range of a few million years outside that is possible.

\section{Igneous activity and later Ross movements}

With an age of $500 \mathrm{Ma}$, the volcanic Gambacorta Formation of the eastern Neptune Range is upper Middle Cambrianlower Upper Cambrian (Figs 3 \& 8). Within error, it is the same age as the small biotite granite outcrops of the Serpan Gneiss (Van Schmus et al. 1997), present in the eastern part of the same range, some $20-40 \mathrm{~km}$ north of the Gambacorta caldera. These areally restricted exposures of the Serpan
Granite are thought to be part of a much larger intrusion, concealed by snow and ice, whose presence is inferred on the basis of abundant errratic granite blocks and a negative gravity anomaly (Schmidt \& Ford 1969; Storey et al. 1996). We consider these rocks are probably a somewhat subdued expression of the Ross magmatic arc in the Weddell Sea sector of the Transantarctic Mountains.

Synchronously with emplacement of the arc in late Middle Cambrian time, a second deep-water basin outboard of it accumulated greywacke sandstone, shale, and volcanic rocks of the Patuxent Formation (restricted) (Figs $7 \&$ 8). Storey et al. (1992) discussed the geochemistry of igneous rocks from both the Schmidt and Williams hills in an attempt to constrain the tectonic setting of the depositional basin. Felsic rocks have crustal trace element and isotopic characteristics, whereas associated basalts have trace element and rare earth element signatures similar to some rift-related tholeiites. They concluded that the basin probably had an extensional origin on continental crust. Although we have demonstrated that this basin is much younger than Storey et al. (1992) considered it to be, we agree with their interpretation of its extensional origin. Conceivably, it formed at the margin of East Antarctica in a back-arc or even a forearc position during the widespread episode of c. $500 \mathrm{Ma}$ arc development. Extensional regimes are common in such settings, as the overriding plate with its continental lithosphere is pulled towards a retreating hinge (Hamilton 1994).

A second episode of deformation followed after volcanism ceased in the Pensacola Mountains. The resultant folding is traditionally regarded as the principal or even the sole expression of the Ross deformation in the Pensacola Mountains (Ford 1977; Schmidt et al. 1978; Frischbutter 1982; Stump 1995; Storey et al. 1996). This episode of folding, clearly expressed by the areally extensive unconformity at the base of the Neptune Group (Figs 3 \& 8), together with a localized break between the Wiens and Gambacorta formations, we regard as a late-stage Ross event whose intensity in the Pensacola Mountains was much less than that of the early Ross deformation. The age of this event is poorly constrained by the age of the Wiens Formation and the Neptune Group, but is Late Cambrian or younger.

\section{Age of deformation elsewhere in the Transantarctic Mountains}

\section{Central Transantarctic Mountains}

A significant reinterpretation of the Ross orogeny in the central Transantarctic Mountains is a necessary consequence 


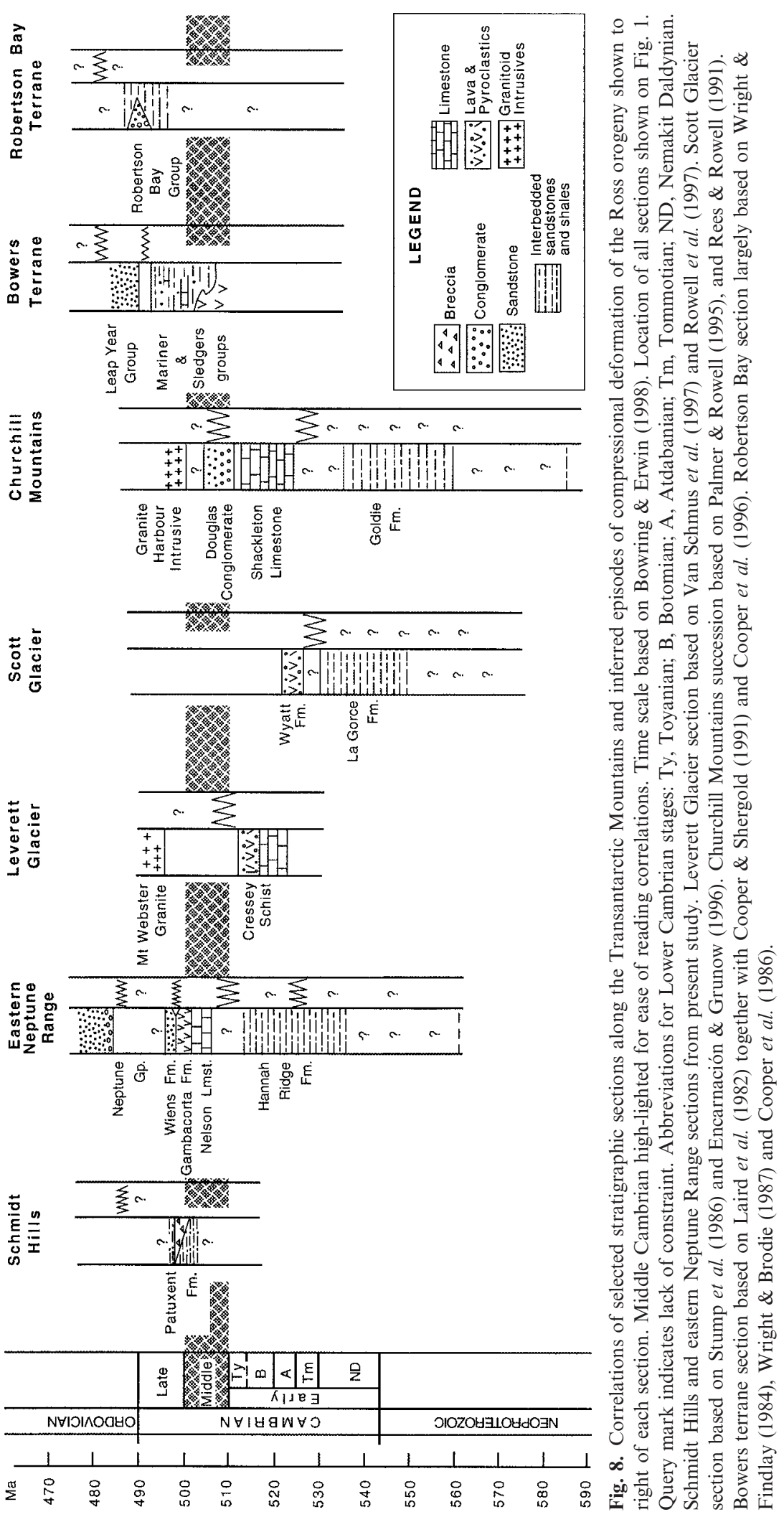


of recognizing that $c .500 \mathrm{Ma}$ is a latest Middle Cambrian or early Late Cambrian age. Undeformed granitoid intrusions yielding Late Cambrian and Early Ordovician ages are known in these mountains (e.g., Thiel Mountains, Pankhurst et al. 1988; Dry Valley area, Parkinson 1994; Encarnación \& Grunow 1996; eastern Queen Maud Mountains, Van Schmus et al. 1995, 1997) but, as Encarnación \& Grunow (1996) have noted, the $c .500 \mathrm{Ma}$ intrusions are 'post-tectonic' in the sense of showing no obvious post-crystallization deformation. These c. $500 \mathrm{Ma}$ intrusions, however, are late Mid-Cambrian or early Late Cambrian; they are not Ordovician.

The quality and density of isotopic and faunal control on deformation age varies along the length of the range. In the Queen Maud Mountains, around Leverett Glacier (Figs 1 \& 8 ), metavolcanics in the Cressey Schists yield protolith magmatic zircons with a U-Pb zircon age of $515 \pm 4 \mathrm{Ma}$, whereas the unfoliated Mt Webster Granite is $494 \pm 3$ Ma (Van Schmus et al. 1997). That the folding here occurred during the Mid- or early Late Cambrian is supported by intensely deformed limestone that has locally yielded a late Early Cambrian (Botomian) archaeocyath fauna (Rowell et al. 1997). This folding is clearly younger than that recorded in the adjacent Scott Glacier area, where deformation of the La Gorce Formation is demonstrably older than volcanism and intrusion associated with the Wyatt Formation (Stump et al. 1986), now known to be of Early Cambrian age ( $526 \pm 2 \mathrm{Ma}$, Encarnación \& Grunow 1996). Thus, in the Queen Maud Mountains, seemingly at least two episodes of early Ross folding are recognizable. At least one episode of later Ross folding may also have affected part of this area, because the upper Middle Cambrian Taylor Formation of the Shackleton Glacier area is folded (Encarnación et al. 1999).

Although published isotopic data are sparse in the long sector of the Transantarctic Mountains between Nimrod Glacier and the Dry Valley region of southern Victoria Land, available stratigraphic information is compatible with most deformation being older than $500 \mathrm{Ma}$. This deformation was thus also of pre-late Mid-Cambrian or early Late Cambrian age and multiple deformation episodes may have been involved (Fig. 8). In the Churchill Mountains, between Nimrod and Byrd glaciers, the folded Shackleton Limestone with its Atdabanian, Botomian, and possible Toyanian trilobite fauna (Palmer \& Rowell 1995) was interpreted as having been deposited subsequent to earlier folding and erosion of the underlying Goldie Formation, which is part of the Beardmore Group (Laird et al. 1971). This interpretation has been challenged, however. Most, if not all, known exposures of the contact between the two units show a faulted boundary; conceivably, folding of both formations was caused by a single progressive deformational event subsequent to deposition of the Shackleton Limestone (Goodge et al. 1999). Initial folding of the Shackleton Limestone certainly preceded deposition of the overlying alluvial fan and braid-plain deposits of the Douglas Conglomerate (Rees \& Rowell 1991). Where the contact between these units is exposed, the Douglas Conglomerate is seen to rest with angular unconformity on the carbonate unit and both mineralized and folded clasts of Shackleton Limestone are present in conglomerate beds, with mineral veins terminating abruptly at clast boundaries. The Douglas Conglomerate itself is locally strongly deformed and faulted. Structural data have been interpreted as showing three deformational events affected it (Rees et al. 1988), but neither the age of the formation nor timing of its deformation are tightly constrained. It is unknown whether deposition and perhaps deformation of the Douglas Conglomerate followed almost immediately upon folding and erosion of the Shackleton Limestone (Panttaja \& Rees 1991; Rees et al. 1992) or whether they are well separated in time. Stratigraphic evidence shows only that the Douglas Conglomerate is preDevonian. Contacts between the Douglas Conglomerate and Granite Harbor Intrusives are also unknown, but intrusive rocks in the area seemingly are not deformed (Encarnación \& Grunow 1996) and are c. $500 \mathrm{Ma}$ in age (Gunner \& Mattinson 1975). Thus deposition and deformation of the Douglas Conglomerate was probably pre-500 Ma (Fig. 8). Such an interpretation is consistent with observations in the Dry Valley region, where intrusives as young as $505 \mathrm{Ma}$ are foliated and others of about $498 \mathrm{Ma}$ age are 'post-tectonic' (Encarnación \& Grunow 1996).

\section{Bowers and Robertson Bay terranes, northern Victoria Land}

Although differences of opinion exist on how the Bowers and Robertson Bay terranes were juxtaposed and accreted to East Antarctica (e.g., Weaver et al. 1984; Bradshaw et al. 1985; Kleinschmidt \& Tessensohn 1987; Gibson 1987; Dallmeyer \& Wright 1992; Wright \& Dallmeyer 1991; Musumeci 1999; Musumeci et al. 1999; and others reviewed by Stump 1995), isotopic, stratigraphic and palaeontological evidence indicate that folding of the rocks in these terranes was of markedly different age from that of the principal phases of Ross deformation elsewhere in the Transantarctic Mountains (Fig. 8).

In the Bowers terrane, rocks of the Bowers Supergroup are divided into three groups. The basal Sledgers Group consists of thick, largely basaltic volcanic rocks interbedded with sandstone and mudstone overlain by shallow marine deposits of the Mariner Group (Laird et al. 1982). A regional unconformity truncates beds of the Mariner and Sledgers groups (Laird et al. 1982) and is overlain by sands and conglomerates of the Leap Year Group that are locally several thousand metres thick (Laird \& Bradshaw 1983). The age of strata below the Leap Year Group is well-controlled by trilobite faunas correlated with Australian biostratigraphic zones and stages (Cooper \& Shergold 1991; Cooper et al. 1996; Fig. 8). The oldest beds are upper Middle Cambrian and the younger ones are middle Upper Cambrian. The Leap Year Group lacks body fossils but trace fossils are consistent with a late Cambrian to Ordovician age (Cooper \& Shergold 1991; Laird 1991a). The age of rocks adjacent to the regional unconformity implies that modest uplift and tilting occurred some time after the mid-Late Cambrian and before deposition of the Leap Year Group. The principal episode of deformation, which produced generally open folds (reviewed by Stump 1995), affected all rocks in the Bowers terrane and from stratigraphic evidence is demonstrably post-middle Late Cambrian. Recent $\mathrm{Pb}-\mathrm{Pb}$ titanite ages of $490-480 \mathrm{Ma}$ from a synkinematic intrusion in the shear zone marking the inboard margin of the Bowers terrane strongly suggest that terrane accretion occurred during the Early Ordovician (Musumeci et al. 1999; Fig. 8). Folding is probably of the same age.

Stratigraphic evidence of deformational history in the Roberston Bay terrane is somewhat similar to that of the Bowers terrane, but isotopic data suggest deformation may have commenced earlier and been more protracted (Dallmeyer \& Wright 1992; Wright \& Dallmeyer 1991). In this terrane, 
strata of the Robertson Bay Group consist of a few thousand metres of rhythmically alternating greywacke sandstone and slate whose base is not exposed. These strata are undivided but are seemingly overlain by the Handler Formation, which is included in the group (Wright \& Findlay 1984; Wright \& Brodie 1987). In its upper part, the Handler Formation contains large blocks of limestone, interpreted as the product of a marine debris flow (Wright \& Brodie 1987). These blocks have yielded uppermost Cambrian and lowermost Ordovician fossils (Burrett \& Findley 1984; Wright et al. 1984); the Robertson Bay Group is therefore early Ordovician or younger in its upper beds. The remainder of the group lacks reliable age control but acritarchs suggest some of the beds may be Cambrian or even upper Neoproterozoic (Cooper et al. 1983). Stump (1995), citing the work of Kleinschmidt \& Skinner (1981), Findlay \& Field (1983) and Findlay (1986), states that over most of its outcrop area, the Robertson Bay Group has been deformed in a single episode of upright folding. Both K-Ar whole-rock ages (Adams \& Kreuzer 1984) and $\mathrm{Ar}-\mathrm{Ar}$ dating of axial plane cleavage formation (Wright \& Dallmeyer 1991; Dallmeyer \& Wright 1992), however, have been interpreted to show diachronicity within the Robertson Bay terrane. Cleavage formation seemingly commenced earlier near the western, inboard margin of the Robertson Bay terrane and was developed at c. $500 \mathrm{Ma}$ in latest Mid-Cambrian-early Late Cambrian time. Towards the eastern, outboard terrane margin, axial plane cleavage did not form until later in the Ordovician (c. $460 \mathrm{Ma}$ ). The stratigraphic and tectonic implications of these isotopic ages are not fully resolved.

In neither the Bowers terrane nor the Robertson Bay terrane does a stratigraphic record exist of early phases of the Ross orogeny, which are the principal phases of folding in the central Transantarctic Mountains and the Pensacola Mountains Conceivably, in both terranes rocks of sufficiently old age are not exposed. Alternatively, the terranes may have been outboard from the active paleo-Pacific margin of East Antarctica during the Early and Mid-Cambrian. The principal deformation in both terranes, in contrast, is probably Ordovician and may have been associated with plate-margin accretion. It is perhaps noteworthy that, as discussed previously, where minor late-stage Ross orogenic deformation is documented in the stratigraphic record elsewhere in the Transantarctic Mountains (Fig. 8), these movements are broadly of the same age and thus potentially may be a response to the same primary cause.

\section{Conclusions}

The oldest supracrustal rocks exposed in the Pensacola Mountains forming the Hannah Ridge Formation are no older than latest Neoproterozoic and are probably Early Cambrian. No direct evidence exists that this segment of the East Antartic craton was formed by mid-Neoproterozoic rifting although strata below those exposed and dated could be older than $560 \mathrm{Ma}$. These siliciclastic rocks were folded, uplifted, and eroded prior to the late Mid-Cambrian in one or more compressional events, previously attributed to the Beardmore orogeny. We consider this deformation an early, but intense, expression of the Ross orogeny. Subsequently, carbonate platform deposits accumulated over the region in the late Mid-Cambrian, but carbonate production was shut down by extensive felsic volcanism at c. $500 \mathrm{Ma}$, in latest MidCambrian or earliest Late Cambrian time. This volcanism seemingly developed in an extensional setting near a shelf margin located in the eastern Neptune Range. Seaward of the shelf, a deep basin accumulated mass-movement deposits from the shelf margin together with thick turbidite-rich siliciclastic deposits that now form the Patuxent Formation. The entire area was affected by a later episode of Ross compression in the Late Cambrian or Ordovician, but this deformation was relatively mild and is poorly dated.

Elsewhere in the central Transantarctic Mountains, the chronology of Ross deformation is broadly similar. Although the timing of deformation was probably not synchronous along the length of the range, peak deformation was essentially complete by the close of the late Mid-Cambrian, even as igneous activity continued into the Ordovician. The consequences of Late Cambrian or Early Ordovician deformation, long thought to have been the time of maximum Ross orogenic deformation, are either mild or even unrecognizable along most of the central Transantarctic Mountains.

Only in the accreted Bowers and Robertson Bay terranes of northern Victoria Land can most deformation be attributed to Early Ordovician or younger compression, probably associated with plate-margin accretion. Although outcrops include demonstrable upper Middle Cambrian rocks, older strata are unknown and the effects of early phases of the Ross orogeny, if present, are consequently undocumented.

Field work was funded through the Office of Polar Programs of the National Science Foundation under grant DPP 9117444. Laboratory work was supported by National Science Foundation grants DPP 9117444 and EAR 9404891 together with funding from the University of Kansas and the Department of Geology at University of Kansas. We are grateful to these agencies and institutions. We also acknowledge with gratitude the support of colleagues. We are indebted to Peg Rees, Larry McKenna, and Pete Braddock for their enthusiastic help in the field, to Dick Robison and A.R. (Pete) Palmer for their assistance with trilobite identifications and preparation and to John Goodge, Bob Pankhurst and Randy Parrish for many suggestions on an earlier version of the manuscript. We could not have completed this work without the logistical support of the National Science Foundation and British Antarctic Survey. This paper is a contribution to IGCP project 436 (Pacific Gondwana Margin).

\section{References}

Adams, C.J. \& Kreuzer, H. 1984. Potassium-argon age studies of slates and phyllites from the Bowers and Robertson Bay terranes, north Victoria Land, Antarctica. Geologisches Jahrbuch, 60, 265-288.

Barrett, P.J. 1991. The Devonian to Jurassic Beacon Supergroup of the Transantarctic Mountains and correlatives in other parts of Antarctica. In: Tingey, R.J. (ed.) The Geology of Antarctica. Clarendon Press, Oxford, $120-152$.

Borg, S.G. \& DePaolo, D.J. 1991. A tectonic model of the Antaretic Gondwana margin with implications for southeaastern Australia: Isotopic and geochemical evidence. Tectonophysics, 196, 339-358.

Bowring, S.A. \& ERwin, D.H. 1998. A new look at evolutionary rates in deep time: Uniting paleontology and high precision geochronology. GSA Today, 8, 1-8.

Bradshaw, J.D., Weaver, S.D. \& Laird, M.G. 1985. Suspect terranes in north Victoria Land, Antarctica. In: Howell, D.C., JoneS, D.L., Cox, A. \& Nur, A. (eds) Circum-Pacific Terrane Conference Proceedings. Stanford University Press, 36-39.

Burrett, C.F. \& Findlay, R.H. 1984. Cambrian and Ordovician conodonts from the Robertson Bay Group, Antarctica, and their tectonic significance. Nature, 307, 723-726.

Cooper, R.A., JAGO, J.B. \& BeGG, J.G. 1996. Cambrian trilobites from Northern Victoria Land, Antarctica, and their stratigraphic implications. New Zealand Journal of Geology and Geophysics, 39, 363-387. 
CoOper, R.A. \& Shergold, J.H. 1991. Palaeozoic invertebrates of Antarctica. In: Tingey, R.J. (ed.) The Geology of Antarctica. Clarendon Press, Oxford, 455-486.

Cooper, R.A., Jago, J.B., Rowell, A.J. \& Braddock, P. 1983. Age and correlation of the Cambro-Ordovician Bowers Supergroup, northern Victoria Land. In: Oliver, R.L., James, P.R. \& JAgo, J.B. (eds) Antarctic Earth Science. Australian Academy of Science, Canberra, 128-131.

Dallmeyer, R.D. \& Wright, T.O. 1992. Diachronous cleavage development in the Robertson Bay terrane, northern Victoria Land, Antarctica: Tectonic implications. Tectonics, 11, 437-448.

DAlzIEL, I.W.D. 1991. Pacific margins of Laurentia and East AntarcticaAustralia as a conjugate rift pair: Evidence and implications for an Eocambrian supercontinent. Geology, 19, 598-601.

Dalziel, I.W.D. 1992. Antarctica; a tale of two supercontinents. Annual Review of Earth and Planetary Science, 20, 501-526.

Davidek, K.E., Landing, E., Bowring, S.A., Westrop, S.R., Rushton, A.W.A., Fortey, R.A. \& Adrian, J.M. 1998. New uppermost Cambrian $\mathrm{U}-\mathrm{Pb}$ date from Avalonian Wales and the age of the Cambrian-Ordovician boundary. Geological Magazine, 135, 305-309.

EAstin, R. 1970. Geochronology of the basement rocks of the central Transantarctic Mountains, Antarctica; Pensacola Mountains. In: FAURE, G., Eastin, R., Gunner, J.D., Hill, R.L., Jones, L.M. \& Elliot, D.H (eds) Studies in the geochronology and geochemistry of the Transantarctic Mountains. Ohio State University. Research Foundation Report, RF 2411, $67-114$

EnCARNACIÓN, J. \& GrunOw, A. 1996. Changing magmatic and tectonic styles along the paleo-Pacific margin of Gondwana and the onset of early Paleozoic magmatism in Antarctica. Tectonics, 15, 1325-1341.

Encarnación, J., Rowell, A.J. \& Grunow, A. 1999. A U-Pb age for the Middle Cambrian Taylor Formation, Antarctica: Implications for the Cambrian Time Scale. Journal of Geology, 107, 497-504.

Evans, K.R., Fetter, A.H., McKenna, L.W., Rowell, A.J. \& Van Schmus, W.R. 1994. Deep-water Lower Paleozoic deposition off the Antarctic segment of Gondwana. Geological Society of America, Abstracts with Programs, 26(No. 7), A504.

Evans, K.R., Rowell, A. J. \& Rees, M.N. 1995. Sea-level changes and stratigraphy of the Nelson Limestone (Middle Cambrian), Neptune Range, Antarctica. Journal of Sedimentary Research, B65, 32-43.

Faure, G., Eastin, R., Ray, P.T., Mclelland, D. \& Schultz, C. 1979. Geochronology of igneous and metamorphic rocks, central Transantarctic Mountains. In: Llaskar, B. \& RAO, C.S. (eds) Fourth International Gondwana Symposium Papers, 1. Delhi, 805-813.

FindLAY, R.H. 1986. Structural geology of the Robertson Bay and Millen terranes, northern Victoria Land, Antarctica. In: STUMP, E. (ed.) Geological investigations in northern Victoria Land, Antarctica. American Geophysical Union. Research Series, 46, 91-114.

Findlay, R.H. \& Field, B.D. 1983. Tectonic significance of deformations affecting the Robertson Bay Group and associated rocks, northern Victoria Land, Antarctica. In: Oliver, R.L., JAmes, P.R. \& JAGO, J.B. (eds) Antarctic Earth Science. Australian Academy of Science, Canberra, $107-112$.

FORD, A.B. 1977. Geological comparison of the Shackleton Range and the Pensacola Mountains during the 22nd Soviet Antarctic Expedition. Antarctic Journal of the United States, 12, 88-90.

Frischbutter, A. 1981. Gliederung, Bau und Entwicklung des Transantarktischen Gebirges im Bereich der Neptune Range (Antarktis). Teil I: Stratigraphie und regionale Einbindung. Zeitschrift für Geologische Wissenschaften, 9, 817-833.

Frischbutter, A. 1982. Gliederung, Bau und Entwicklung des Transantarktischen Gebirges im Bereich der Neptune Range (Antarktis). Teil II: Deformation, metamorphose und gesantentwickling. Zeitschrift für Geologische Wissenschaften, 10, 165-180.

Frischbutter, A. \& Vogel, P. 1985. Contributions to the Geochemistry of Magmatic Rocks in the Upper Precambrian Lower Palaeozoic Profile of the Neptune Range, Transantarctic Mountains, Antarctica. Zeitschrift für Geologische Wissenschaften, 13, 345-357.

GiBson, G.M. 1987. Metamorphism and deformation in the Bowers Supergroup: Implications for terrane acretion in northern Victoria Land. In: LEITCH, E.C. \& Scheibner, E. (eds) Terrane accretion and orogenic belts. American Geophysical Union. Geodynamic Series, 19, 207-219.

Goodge, J.W. 1997. Latest Neoproterozoic basin inversion of the Beardmore Group, central Transantarctic Mountains, Antarctica. Tectonics, 16, $682-701$.

Goodge, J.W., Hansen, V.L., Peacock, S.M., Smith, B.K. \& Walker, N.W. 1993a. Kinematic evolution of the Miller Range shear zone, central Transantarctic Mountains, Antarctica and implications for Neoproterozoic to Early Cambrian tectonics of the East Antarctic margin of Gondwana. Tectonics, 12, 1460-1478.

Goodge, J.W., Walker, N.W. \& Hansen, V.L. 1993b. NeoproterozoicCambrian basement-involved orogenesis within the Antarctic margin of Gondwana. Geology, 21, 37-40.

Goodge, J.W., Paulson, T., Deering, S.K., Encarnacin, J. \& Watkeys, M. 1999. Progressive (?) deformation of supracrustal rocks in the Ross orogen, central Transantarctic Mountains. 8th International Symposium on Antarctic Earth Sciences, Programme and Abstracts, 121.

Grindley, G.W. \& McDougall, I. 1969. Age and correlation of the Nimrod Group and other Precambrian rock units in the Central Transantarctic Mountains, Antarctica. New Zealand Journal of Geology and Geophysics, 12, 391-411.

Grindley, G.W. \& WARREN, G. 1964. Stratigraphic nomenclature and correlation in the western Ross Sea region. In: AdIE, R.J. (ed.) Antarctic Geology. North Holland, Amsterdam, 314-333.

GunN, B.N. \& Warren, G. 1962. Geology of Victoria Land between the Mawson and Mullock Glaciers, Antarctica. New Zealand Geological Survey Bulletin, 71.

Gunner, J. \& Mattinson, J.M. 1975. Rb-Sr and U-Pb isotopic ages of granites in the central Transantarctic Mountains. Geological Magazine, 112, 25-31.

Hamilton, W.B. 1994. Subduction systems and magmatism. In: Smellie, J.L. (ed.) Volcanism Associated with Extension at Consuming Plate Margins. Geological Society, London. Special Publications, 81, 3-28.

Hoffman, P.E. 1991. Did the breakout of Laurentia turn Gondwana inside-out? Science, 252, 1409-1412.

JAGO, J.B. \& HaINES, P.W. 1998. Recent radiometric dating of some Cambrian rocks in southern Australia: relevance to the Cambrian time scale. Revista Española de Paleontologia, No. Extr., 115-122.

JAGO, J.B. \& McNeIL, A.W. 1997. A late Middle Cambrian shallow-water trilobite fauna from the Mt. Reid Volcanics, northwestern Tasmania. Papers and Proceedings of the Royal Society of Tasmania, 131, 85-90.

Kleinschmidt, G. \& Skinner, D.N.B. 1981. Deformation styles in the basement rocks of North Victoria Land, Antarctica. Geologisches Jahrbuch, B41, 155-199.

Kleinschmidt, G. \& Tessensohn, F. 1987. Early Paleozoic westward subduction at the Pacific margin of Gondwana. In: McKenzIE, G.D. (ed.) Gondwana Six: Structure, tectonics and geophysics. American Geophysical Union. Geophysical Monographs, 40, 89-105.

KroGH, T.E. 1973. A low contamination method for hydrothermal decomposition of zircon and extraction of $\mathrm{U}$ and $\mathrm{Pb}$ for isotopic age determinations. Geochimica et Cosmochimica Acta, 37, 485-494.

KroGH, T.E. 1982. Improved accuracy of U-Pb zircon ages by the creation of one or more concordant systems using an air abrasion technique. Geochimica et Cosmochimica Acta, 46, 637-649.

LAIRD, M.G. 1963. Geomorphology and stratigraphy of the Nimrod GlacierBeaumont Bay region, southern Victoria Land, Antarctica. New Zealand Journal of Geology and Geophysics, 6, 465-484.

LAIRD, M.G. 1981. Lower Palaeozoic rocks of Antarctica. In: Holland, D.H. (ed.) Lower Palaeozoic of the Middle East, Eastern and Southern Africa, and Antarctica. John Wiley and Sons, London, 257-314.

LAIRD, M.G. 1991a. The Late Proterozoic-Middle Palaeozoic rocks of Antarctica. In: Tingey, R.J. (ed.) The Geology of Antarctica. Clarendon Press, Oxford, 74-119.

LAIRD, M.G. 1991b. Lower-mid-Palaeozoic sedimentation and tectonic patterns on the palaeo-Pacific margin of Antarctica. In: Thomson, M.R.A., CRAmE, J.A. \& Thomson, J.W. (eds) Geological Evolution of Antarctica. Cambridge University Press, 177-183.

Laird, M.G. \& Bradshaw, J.D. 1983. New data on the lower Paleozoic Bowers Supergroup, northern Victoria Land. In: OLIVER, R.L., JAMES, P.R. \& JAGO, J.B. (eds) Antarctic Earth Science. Australian Academy of Science, Canberra, 123-126.

Laird, M.G., Mansergh, G.D. \& Chapell, J.M.A. 1971. Geology of the Central Nimrod Glacier area, Antarctica. New Zealand Journal of Geology and Geophysics, 14, 427-468.

Laird, M.G., Bradshaw, J.D. \& Wodzicki, A. 1982. Stratigraphy of the late Precambrian and early Paleozoic Bowers Supergroup, northern Victoria Land, Antarctica. In: Craddock, C. (ed.) Antarctic Geoscience. University of Wisconsin Press, Madison, 535-542.

Landing, E., Bowing, S.A., Davidek, K., Westrop, S.R., Geyer, G. \& Heldmaier, W. 1998. Duration of the Early Cambrian: U-Pb age of volcanic ashes from Avalon and Gondwana. Canadian Journal of Earth Sciences, 35, 329-338.

LANDING, E. \& WeSTrop, S.R. 1998. Cambrian faunal sequence and depositional history of Avalonian Newfoundland and New Brunswick: Field Workshop. 
In: Landing, E. \& Westrop, S.R. (eds) Avalon 1997 The Cambrian Standard. New York State Museum. Bulletin, 492, 5-75.

Landing, E., Bowring, S.A., Fortey, R.A. \& Davidek, K.L. 1997. U-Pb zircon date from Avalonian Cape Breton Island and geochronologic calibration of the Early Ordovician. Canadian Journal of Earth Sciences, 34, 724-730.

LuDwIG, K. 1993a. PBDAT: A computer program for processing $P b-U-T h$ isotope data, version 1.24. United States Geological Survey Open File Report, 88-542 (revision of June 22, 1993).

LUDWIG, K. 1993b. ISOPLOT: A plotting and regression program for radiogenic isotope data, version 2.70. United States Geological Survey Open File Report, 91-445 (revision of June 9, 1993).

Millar, I.L. \& Storey, B.C. 1995. Early Palaeozoic rather than Neoproterozoic volcanism and rifting within the Transantarctic Mountains. Journal of the Geological Society, London, 152, 417-420.

Moores, E.M. 1991. The southwest U.S.-East Antarctic (SWEAT) connection: A hypothesis. Geology, 19, 425-428.

MusumeCI, G. 1999. Magmatic belts in accretionary margins, a key for tectonic evolution: the Tonalite Belt of North Victoria Land (East Antarctica). Journal of the Geological Society, London, 156, 177-189.

Musumeci, G., Kramers, J. \& Pertusati, P.C. 1999. Pb/Pb titanite age of a tonalite belt: New data on Early Paleozoic terrane accretion along the Gondwana margin of the East Antarctic craton (North Victoria Land, Antarctica). 8th International Symposium on Antarctic Earth Sciences, Programme and Abstracts, 221.

Myrow, P.M. \& Goodge, J.W. 1999. Reinterpretation of depositional and tectonic setting of Neoproterozoic strata, Transantarctic Mountains. 8th International Symposium on Antarctic Earth Sciences, Programme and Abstracts, 222.

Palmer, A.R. \& Gatehouse, C.G. 1972. Early and Middle Cambrian trilobites from Antarctica. In: Contributions to the Geology of Antarctica. United States Geological Survey, Professional Paper, 456D, D1-D37.

Palmer, A.R. \& Rowell, A.J. 1995. Early Cambrian trilobites from the Shackleton Limestone of the central Transantarctic Mountains. Paleontological Society Memoirs, 45.

Pankhurst, R.J., Storey, B.C., Millar, I.L., Macdonald, D.I.M. \& Vennum, W.R. 1988. Cambro-Ordovician magmatism in the Thiel Mountains, Transantarctic Mountains, and implications for the Beardmore orogeny. Geology, 16, 246-249.

Panttaja, S.K. \& Rees, M.N. 1991. Provenance, age, and tectonic setting of lower Paleozoic siliciclastics in the Central Transantarctic Mountains. Geological Society of America Abstracts with Program, 23, 364.

Parkinson, D.L. 1994. U-Pb zircon and monzanite ages, $\mathrm{Pb}, \mathrm{Sr}, \mathrm{Nd}$, isotopic data for Ross orogeny age intrusives from south Victoria Land Antarctica. EOS, Transactions American Geophysical Union, 75, 692.

PARRISH, R.R. 1987. An improved micro-capsule for zircon dissolution in U-Pb geochronology. Isotope Geoscience, 66, 99-102.

Perkins, C. \& Walshe, J.L. 1993. Geochronology of the Mount Read Volcanics, Tasmania, Australia. Economic Geology, 88, 1176-1197.

ReEs, M.N., Duebendorfer, E.M. \& Rowell, A.J. 1990. The Skelton Group, southern Victoria Land. Antarctic Journal of the United States, Review 1989, 24, 21-24.

Rees, M.N. \& Rowell, A.J. 1991. The pre-Devonian Palaeozoic clastics of the central Transantarctic Mountains: stratigraphy and depositional settings. In: Thomson, M.R.A., Crame, J.A. \& Thomson, J.W. (eds) Geological Evolution of Antarctica. Cambridge University Press, 187-192.

Rees, M.N., Girty, G.H., Panttaja, S.K. \& Braddock, P. 1988. Multiple phases of early Paleozoic deformation in the central Transantarctic Mountains. Antarctic Journal of the United States, Review 1987, 22, 33-35.

Rees, M.N., Wallin, E., Rowell, A.J. \& Stump, E. 1992. Were East Antarctica and western North America conjugate rift pairs in the Cambrian? Geological Society of America (Cordilleran section), Abstract with Programs, 24, 77.

Rowell, A.J. \& HeNDERSON, R.A. 1978. New genera of acrotretids from the Cambrian of Australia and the United States. Paleontological Contributions, University of Kansas, Paper, 93.

Rowell, A.J., Refs, M.N. \& Evans, K.R. 1992. Evidence of major Middle Cambrian deformation in the Ross orogen, Antarctica. Geology, 20, 31-34.

Rowell, A.J., Refs, M.N., Dufbendorfer, E.M., Waluin, E.T., Van Schmus, W.R. \& SMith, E.I. 1993. An active Neoproterozoic margin: Evidence from the Skelton Glacier area, Transantarctic Mountains. Journal of the Geological Society, London, 150, 677-682.

Rowell, A.J., Van Schmus, W.R., McKenna, L.W. \& Evans, K.R. 1995. Early Paleozoic continental-rise deposition off East Antarctica: The Patuxent
Formation of the Pensacola Mountains. Antarctic Journal of the United States, Review 1994, 29, 42-44.

Rowell, A.J., Gonzales, S.A., McKenna, L.W., Evans, K.R., Stump, E. \& Van Schmus, W.R. 1997. Lower Paleozoic rocks in the Queen Maud Mountains: Revised ages and significance. In: RicCI, C.A. (ed.) The Antarctic Region: Geological Evolution and Processes. Terra Antarctica, Siena, 201-207.

Schmidt, D.L. \& Ford, A.B. 1969. Geology of the Pensacola and Thiel Mountains. American Geographical Map Folio Series, folio, 12, V.

Schmidt, D.L., Dover, J.H., Ford, A.B. \& Brown, R.D. 1964. Geology of the Patuxent Mountains. In: AdIE, R.J. (ed.) Antarctic Geology. North Holland, Amsterdam, 276-283.

Schmidt, D.L., Williams, P.L., Nelson, W.H. \& Ege, J.R. 1965. Upper Precambrian and Paleozoic stratigraphy and structure of the Neptune Range, Antarctica. In: Contributions to the Geology of Antarctica. United States Geological Survey, Professional Paper, 525-D, D112-D119.

Schmidt, D.L. Williams, P.L. \& Nelson, W.H. 1978. Geologic map of the Schmidt Hills quadrangle and part of the Gambacorta Peak quadrangle, Pensacola Mountains, Antarctica. United States Geological Survey, United States Antarctic Research Program, Map, A-8, Reston.

Shergold, J.H. 1995. Timescales 1. Cambrian. Australian Geological Survey Organization. Record, 1995/30, Canberra.

SKINNER, D.N.B. 1982. Stratigraphy and structure of lower grade metasediments of Skelton Group, McMurdo Sound: Does Teall Greywacke really exist. In: Craddock, C. (ed.) Antarctic Science. University of Wisconsin Press, Madison, 555-563.

Solov'ev, I.A., Popov, L.E. \& Samsonov, V.V. 1984. New data on the Upper Cambrian fauna of the Ellsworth and Pensacola Mountains (Western Antarctica). Antarktika, 23, 46-71.

StaceY, J.S. \& Kramers, J.D. 1975. Approximation of terrestrial lead isotope evolution by a two-stage model. Earth and Planetary Science Letters, 26, 207-221.

Steiger, R.H. \& JäGeR, E. 1977. Subcommission on geochronology: convention on the use of decay constants in geo- and cosmochronology. Earth and Planetary Science Letters, 36, 359-362.

Storey, B.C., Alabaster, T., Macdonald, D.I.M., Millar, I.L., Pankhurst, R.J. \& Dalziel, I.W.D. 1992. Upper Proterozoic rift-related rocks in the Pensacola Mountains, Antarctica: Precursors to continental breakup? Tectonics, 11, 1392-1405.

Storey, B.C., Macdonald, D.I.M., Dalziel, I.W.D., Isbell, J.L. \& Millar, I.L. 1996. Early Paleozoic sedimentation, magmatism, and deformation in the Pensacola Mountains, Antarctica: The significance of the Ross orogeny. Geological Society of America Bulletin, 108, 685-707.

Stump, E. 1995. The Ross orogen of the Transantarctic Mountains. Cambridge University Press.

Stump, E., Smit, J.H. \& Self, S. 1986. Timing of events during the late Proterozoic Beardmore orogeny, Antarctica. Geological Society of America, Bulletin, 97, 953-965.

Stump, E., Edgerton, D.G. \& Korsch, R.J. 1999. Tectonic model for the Ross orogen from southern Victoria Land to the Queen Maud Mountains: Strain partitioning in both space and time. 8th International Symposium on Antarctic Earth Sciences, Programme and Abstracts, 296.

Tröger, K.A. \& Weber, W. 1985. Description of a Cambrian fauna from the Neptune Range, Pensacola Mountains, Antarctica. Zeitschrift fur geologischen Wissenschaften, Berlin, 13, 359-367.

Van Schmus, W.R., McKenna, L.W., Gonzales, D.A. \& Rowell, A.J. 1995 $\mathrm{U} / \mathrm{Pb}$ geochronology of parts of the Pensacola, Harold Byrd, and Queen Maud Mountains, Antarctica. VII International Symposium on Antarctic Earth Sciences, Abstracts. Siena, 390.

Van Schmus, W.R., McKenna, L.W., Gonzales, D.A. \& Rowell, A.J. 1997. $\mathrm{U} / \mathrm{Pb}$ geochronology of parts of the Pensacola, Harold Byrd, and Queen Maud Mountains, Antarctica. In: RICCI, C.A. (ed.) The Antarctic Region: Geological Evolution and Processes. Terra Antarctica, Siena, 187-200.

Weaver, S.D., Bradshaw, J.D. \& Laird, M.G. 1984. Geochemistry of Cambrian volcanics of the Bowers Supergroup and implications for the Early Paleozoic tectonic evolution of northern Victoria Land, Antarctica. Earth and Planetary Science Letters, 68, 128-140.

Wright, T.O. \& Brodie, C. 1987. The Handler Formation, a new unit of the Robertson Bay Group, northern Victoria Land, Antarctica. In: McKenZIE, G.D. (ed.) Gondwana Six: Structure tectonics and geophysics. American Geophysical Union. Geophysical Monographs, 40, 25-29.

WRight, T.O. \& DALLMEYER, R.D. 1991. The age of cleavage development in the Ross orogen, northern Victoria Land, Antarctica: Evidence from ${ }^{40} \mathrm{Ar} /{ }^{39} \mathrm{Ar}$ whole-rock slate ages. Journal of Structural Geology, 13, 677-690.

Wright, T.O. \& FindLAY, R.H. 1984. Relationships between the Robertson Bay Group and the Bowers Supergroup: New progress and complications from 
the Victory Mountains, North Victoria Land. Geologisches Jahrbuch, B60, $105-116$.

Wright, T.O., Ross, R.J. \& Repetski, J.E. 1984. Newly discovered youngest Cambrian or oldest Ordovician fossils from the Robertson Bay terrane (formerly Precambrian), northern Victoria Land, Antarctica. Geology, 12, 301-305.
Zell, M.G. \& Rowell, A.J. 1988. Brachiopods of the Holm Dal Formation (late Middle Cambrian), central North Greenland. In: Peel, J.S. (ed.) Stratigraphy and Palaeontology of the Holm Dal Formation (late Middle Cambrian), central North Greenland. Meddelelelser om Gronland, Geoscience, 20, 119-144.

Received 12 June 2000; revised typescript accepted 7 November 2000. Scientific editing by Randall Parrish. 